\title{
Agency Costs in Apartment Property Management Contracts
}

\author{
Sidney B. Rosenberg* and John B. Corgel**
}

Because fees for property management services are based on gross rental collections rather than on net operating incomes, property managers may not always act in the best interest of property owners. This study is an examination of the agency costs that result from the conflict of interests between owners and managers. A nationwide proprietary sample of 242 apartment properties is analyzed to compare agency costs of four distinct types of ownership structures. Agency costs, measured as operating expenses per square foot, are found to be significantly higher for institutional owners than for noninstitutional owners, but not significantly hïgher in cases where no competition for property management services exists. We conclude that agency costs of property management contracts are significant and the fee provisions of standard property management contracts should be changed to better align the interests of managers and owners.

\section{INTRODUCTION}

Seminal agency theory papers by Ross [13] and Jensen and Meckling [9] explain how separation of ownership and management may affect the structure of modern corporations. Work on corporate and non-corporate agency questions has extended in many directions. Rozeff [14] and Kim and Sorensen [10] found

\footnotetext{
${ }^{\star}$ Department of Finance and Real Estate, Florida Atlantic University, Boca Raton, Florida 33431.

${ }^{* *}$ School of Hotel Administration, Statler Hall, Cornell University, Ithaca, New York 14853.

Date Received: July 31, 1989; Revised: February 19, 1990.
} 
agency costs to be lower for firms with greater concentrations of corporate ownership. Thakor and Ramakrishnan [18] demonstrated the importance of agent monitoring to reduce agency costs. People have also examined how different incentive/ disincentive arrangements affect agent behavior.

This stream of research has spilled over to the study of contractual relationships in the general field of real estate. Solt and Miller [16] recommend no positive incentives for REIT managers; but instead, negative incentives for excessive expenses, high loan loss reserves, losses on property sales, and excessive debt. Zorn and Larsen [20] found that percentage fee incentives in brokerage contracts are superior to a flat fee structure to obtain higher prices for sellers of real estate.

Property management contracts, negotiated between owners of real estate and managers who collect rents, lease space and maintain properties, establish agency relationships that heretofore have not been examined empirically. With increasing institutional ownership of real estate, the problems associated with separation of ownership and management are potentially more serious than in the past. The purpose of this paper is to communicate the results of an empirical examination of agency costs resulting from alternative property management relationships, including those entered into by institutional and private owners. We find that agency costs, as measured by variable operating expenses per square foot, are significantly higher for institutionally owned properties than for properties owned by individuals and small partnerships.

\section{AGENCY RELATIONSHIPS}

Conflicts arise between owners and managers because of differences in economic incentives when management's ownership interest is less than $100 \%$. The costs associated with such conflicts include the costs of monitoring agents, bonding costs, and residual losses in the value of ownership interests in firms and assets (see Jensen and Meckling [9]). Among these, residual losses are potentially the greatest.

Ownership concentration and competition for managerial services may influence the costs of principal and agent relationships. Agency costs increase as management's ownership shares decline, and are lower when ownership is more concentrated, especially in outside owners (Lease, McConnell and Michelson [12]). Agency costs are also affected by how much competition 
exists for management from outside firms and by the costs of replacing management (see Fama [4], Jensen and Meckling [9]). Because future compensation for managers depends on company performance, the responsiveness of managerial labor markets to management performance serves as an effective agency cost control.

The challenge to efficient contracting therefore is to identify provisions that control agency costs when neither competition nor ownership concentration are optimal. There has been much interest in incentive compensation provisions that align the interests of managers with those of owners. Barnea, Haugen and Senbet [1] suggest that the optimal incentive for corporate management consists of executive stock options. However, symmetric incentive contracts, that contain both bonuses for good performance and penalties for poor performance, may produce greater levels of effort from management than bonus-only contracts (Starks [17]). The standard property management contract, such as the contract produced by the Institute of Real Estate Management (IREM) for multifamily properties, contains provisions that do not address the incentives difference between property owners and managers.

\section{THE PROPERTY MANAGEMENT CONTRACT}

The IREM property management agreement establishes compensation for property managers based on a percentage of gross rental collections (i.e., effective gross income). Owners seek to maximize net operating income (i.e., effective gross income less operating expenses) and terminal values of properties. Because the terminal values of income properties are related directly to net operating incomes, long-term net operating income levels are important measures of success in property management relationships. Agents are driven by self-interest to increase gross revenues and reduce vacancies because their compensation is based on collected rents. Conflicts arise because property managers do not have strong incentives to control operating expenses and thus maximize net operating income. In theory, management fees should be based on net operating income, not effective gross income (see Jaffe [7, 8].

The form and terms of the management contracts used for properties in this study are nearly identical to the IREM standard agreement (Kyle [11]). The following provisions of these agreements have a bearing on agency problems between property owners and managers: 


\section{Term and length of the contract}

The term is generally one year with the provision that it may be mutually renewed or cancelled upon payment of a penalty. The contract also provides that if owners intend to sell properties during the term of the management agreement, property managers are given an exclusive agency listing on the property for six months. The one-year renewable term serves as an incentive for agents to achieve the short-term operating goals of the owner; however, this incentive is somewhat mitigated by the penalty for early cancellation. The exclusive brokerage clause discourages early sale of the property, which may be motivated by poor property performance.

\section{Agency authority and powers}

Agents may advertise at any level. This gives agents the incentive to increase advertising expenditure beyond efficient levels because compensation is based upon gross collections, and not net operating income.

Agents have the incentive to sign leases with marginal tenants and "churn" tenants because additional compensation is often payable for leasing activity.

Agents may collect charges for late payment, returned checks, and subleasing charges and not account to owners. This creates an obvious area of potential abuses.

Agents can hire and fire employees. This provision gives managers no incentive to control salary and wage costs and gives owners no control over these activities.

Agents can make alteration expenditures and enter into nonrecurring contracts for amounts within prestated limits. This provision provides for outside control and ratification by owners, but gives agents the ability to make immediate decisions in areas of superior knowledge.

\section{Owner indemnification}

Owners indemnify agents from law suits against the premises. This clearly allocates risk to owners; however, the provision is limited if agents are negligent. 


\section{Compensation}

Basic compensation is a negotiated percentage of gross collection with some minimum level. The agreement also calls for fees for leasing apartments or commercial space, for overseeing construction; other mutually agreeable fees, such as incentive compensation; may also be specified. Basing management fees on a percentage of gross collections and offering incentive compensation for collection of gross rents above a certain level gives agents incentives to maximize performance relative to gross collections.

\section{DATA AND METHODOLOGY}

Four distinct owner-property management relationships are examined in this study. Two of the relationships involve unrelated entities that selected the services of the property management firm under competitive market conditions. These unrelated ownership groups are categorized as either private owners (i.e., private partnerships) or institutional owners (i.e., REITS and public partnerships). The other owners are organizationally related to the subject property management firm. They are similary categorized as either private or institutional owners. The private ownership group is controlled by key executives of the parent company that also owns the property management firm. The individual majority owner of many of the private partnerships is also the majority owner of the parent company. Related private owners exercise extraordinary control over property operations. For example, they can hire and fire property management employees. Related private owners are also knowledgeable about reasonable levels of operating expenses. These related private owners, however, are obligated to use the related property management firm.

The related institutional owners consist of REITs and public partnerships managed by a subsidiary of the parent firm that controls the property management firm. The related institutional group is characterized by widely disbursed ownership and no competition in the selection of property management services. The parent corporation controls both asset managers and property managers within this group, and asset management and property management fees flow to the parent corporation. The potential for conflicts of interest between beneficial owners and 
the parent corporation is great because the control exercised by the widely disbursed ownership group is limited. This grouping of ownership entities allows for the measurement of agency effects in property management contracts through the comparison of agency costs between (1) institutional and private ownership groups, and (2) competitive and non-competitive property management contracting arrangements. All ownership groups (including private related owners) are charged full management fees, which are generally $5 \%$ of effective gross income. Agency costs should be greatest for related institutions that exhibit neither concentrated ownership nor competitive property management selection. They should be lowest for related private owners who offer superior ownership control and knowledge.

The four categories of owner-agent relationships are summarized as follows (the number of observations in each category is shown in parentheses):

\section{Individual/Unrelated (44)}

Individuals and private partnerships unrelated to the property management firm. This is the normative property management relationship wherein services of the property management firm have been contracted on an arm's-length basis in a competitive environment.

\section{Individual/Related (61)}

Individual and private partnerships that are related to the property management firm. This group consists of key executives with ownership interest in the property management firm and in the properties being managed. This ownership entity has both exceptional knowledge of property operations and direct control to hire and fire property managers.

\section{Institutional/Unrelated (14)}

Institutionl owners who are unrelated to the property management firm. These institutions include savings and loan associations, public partnerships, and REITs. This is the normative property management relationship, but because of dispersed ownership, they are 
expected to exercise less control over property operations than related and unrelated individual owners.

\section{Institutional/Related (123)}

Institutional owners who are related to the property management firm. This group consists of REITs and partnerships owned by the general public and managed by a subsidiary of the parent firm.

The availability of data on property management relationships has limited the study in the past of agency problems between property owners and managers. The database used in this study consists of the entire portfolio of one of the nation's largest multifamily housing property management firms. The portfolio includes over 300 garden apartment properties located in 27 states and contains more than 60,000 units. Certain properties were eliminated from consideration because of missing information. Nevertheless, 242 useable observations were retained. The major drawback of this sample is that properties are somewhat concentrated in the southeast and soutwest areas of the U.S.

Data were obtained from the 1986 annual operating statements and the 1986 management summary report for each property and from outside demographic sources. Data on area unemployment and wage rates were taken from Employment and Earnings, U.S. Department of Labor, Bureau of Labor Statistics [19] that shows unemployment and average wages from many MSAs and all states. Percent of white collar employment in 1980, median years of education in 1980, and median income of zip code area for 1987 were obtained from CACI [2].

Theory suggests that agency costs in property management contracts are a function of the relationship between owners and managers, the level of monitoring, monitoring costs, the control exercised by owners, the degree of competition for property management services, the compensation arrangement, and the level of information available to owners. Because the compensation provision in standard property management contracts rewards managers for maximizing effective gross income, operating expenses will vary across properties according to how the relationship between owners and managers is structured, all else being equal. Assuming that all investors require the same risk-adjusted returns, excessive operating expenses affect the residual values of properties because bidders will discount 
properties for deferred maintenance and rent contract problems (e.g., long-term leases with poor quality tenants at below-market rents). ${ }^{1}$

The empirical literature is nearly silent on the relationship between operating expenses and property values. Hoag [6], in a study of factors that affect industrial property prices, found a negative coefficient for operating expenses that is nearly twice its standard error. Hedonic pricing of income properties is in its infancy compared with the progress made in housing.

The agency costs to apartment owners are measured in this study by the level of operating expenses per square foot (OESF). This measure includes all operating expenses except real estate taxes, utilities, casualty insurance expenses, replacement reserves, and capital expenditures that are not generally under the control of property managers and are subject to wide variations across properties. ${ }^{2}$ Operating expenses are related to vectors of: physical characteristics of properties $(P)$, such as unit size and project size; property-specific economic characteristics $(E)$, such as turnover, rent levels, and certain expenditure levels; market-specific economic characteristics $(M)$, such as employment and income; and a set of owner-agent factors $(A)$, For the $i^{\text {th }}$ the property, the relationship is summarized as

$$
O E S F_{i}=f\left(P_{i}, E_{i}, M_{i}, A_{i}\right)+U_{i}
$$

where $U_{i}$ is a random error term.

The independent variables in Table 1 were selected on the basis of previous studies, interviews with property management executives, and available data. They are broadly classified as agency and non-agency variables. The variables INCENTIV, $O W N R S H I P$, and AGENCGRP capture agency effects. Table 2 contains descriptive information for selected variables.

Because $O E S F$ is not spatially deflated, MSASIZE is included in the model. The variables UNITSIZE and $N_{i}$ are introduced to control for property scale factors. A shortcoming of the database is the absence of information about the age of the properties. The

\footnotetext{
${ }^{1}$ We assumed that the expected cost of capital is the same across rental markets except for risk differences. This point was expressed by one of the referees.

${ }^{2}$ Replacement reserves are calculated by appraisers, but generally owners do not set up reserves. Several expense items that would normally be included in replacement reserve accounts were included in the capital improvement account which was also excluded from $O E S F$.
} 


\section{TABLE 1}

Independent Variables

(Dependent Variable-OESF)

\begin{tabular}{|c|c|c|}
\hline Variable & Expected Sign & Explanation \\
\hline RECION $(R)$ & unknown & $\begin{array}{l}\text { Geographic regions following IREM designations, } \\
\text { coded as dummy variables }(R 1 \ldots R 5) \text {. }\end{array}$ \\
\hline MSASIZE & + & MSA size as of 1980 census shown in millions. \\
\hline UNITSIZE & - & Average unit size in square feet. \\
\hline NUMUNITS $(N)$ & $+1-^{*}$ & $\begin{array}{l}\text { Total number of units in the project, coded as } \\
\text { dummy variables (N1 ..N5). }\end{array}$ \\
\hline CAPEXP & + & $\begin{array}{l}\text { Annual expenditure per sq. ft. for property repairs } \\
\text { and capital expenditures (excluded from OESF). }\end{array}$ \\
\hline YRSEDU & - & $\begin{array}{l}\text { Median years of education in the property's zip code } \\
\text { in } 1980 \text {. }\end{array}$ \\
\hline RENTINC & + & $\begin{array}{l}\text { Ratio of average monthly rent annualized to pro- } \\
\text { jected } 1987 \text { median income of the property's zip } \\
\text { code. }\end{array}$ \\
\hline RENTSF & + & Average monthly gross rent per sq. ft. \\
\hline OUTSERV & + & $\begin{array}{l}\text { Annual expenditure per sq. ft. for services from } \\
\text { outside contractors. }\end{array}$ \\
\hline TURNOVER & + & $\begin{array}{l}\text { Ratio of number of units in the project rented in } \\
1986 \text { to total number of units. }\end{array}$ \\
\hline WAGES & + & MSA or state average hourly industrial wage. \\
\hline $\operatorname{AGENCGRP}(A)$ & - & $\begin{array}{l}\text { Type of ownership structure and relationship coded } \\
\text { as dummy variables }(A 1 \ldots A 4) \text {. }\end{array}$ \\
\hline OWNRSHIP & - & $\begin{array}{l}\text { Ownership interest of the principals of the parent } \\
\text { firm. Coded as dummy variables in two groups. } \\
\text { ( } 1=\text { less than } 50 \% \text { ownership). }\end{array}$ \\
\hline INCENTIV & - & $\begin{array}{l}\text { Incentive payments to property managers per sq. ft. } \\
\text { in } 1986 .\end{array}$ \\
\hline
\end{tabular}

"Coefficient signs for the dummy variables in the NUMUNITS group are expected to be positive for projects with less than 200 units and negative for projects with more than 300 units.

level of capital expenditures is assumed to be highly correlated with age, and thus CAPEXP is an instrument for age.

Variations in real costs among localities is controlled for by the introduction of $R_{i}$,WAGES, TURNOVER, OUTSERV, and RENTSF; the latter of which proxies the level of amenity service flows from the apartment properties. Finally, YRSEDU and RENTINC are included to control for differences in tenant and neighborhood quality across properties.

\section{HYPOTHESES}

The first hypothesis (ownership concentration hypothesis) is that operating expenses are higher for properties in which 
owners exercise less direct control and monitoring of operations. Operating expenses should be higher for properties owned by institutions such as pension funds, REITs, and public partnerships than for properties owned by individuals and private partnerships. Individual owners and small groups of owners with direct

TABLE 2

\section{Descriptive Information for Selected Variables}

\begin{tabular}{|c|c|c|c|c|}
\hline Variable & Mean & $\begin{array}{l}\text { Standard } \\
\text { Deviation }\end{array}$ & $\begin{array}{l}\text { Minimum } \\
\text { Value }\end{array}$ & $\begin{array}{l}\text { Maximum } \\
\text { Value }\end{array}$ \\
\hline \multicolumn{5}{|l|}{$\begin{array}{l}\text { OESF: Total annual } \\
\text { variable operating }\end{array}$} \\
\hline $\begin{array}{l}\text { expenses per sq. ft.' } \\
\text { MSASIZE: MSA size as } \\
\text { of } 1980 \text { census (in }\end{array}$ & 1.488 & 0.3151 & 0.7810 & 2.885 \\
\hline & 1.327 & 1.203 & 0.0040 & 7.477 \\
\hline $\begin{array}{l}\text { size (in sq. } \mathrm{ft} \text {.) } \\
C A P E X P \text { : Annual } \\
\text { expenditures per sq. } \mathrm{ft} . \\
\text { for property repairs } \\
\text { and capital expenditures }\end{array}$ & 904.71 & 163.91 & 511 & 1488 \\
\hline $\begin{array}{l}\text { (excluded from OESF) } \\
\text { YRSEDU: Median years of } \\
\text { education in the } \\
\text { property's zip code }\end{array}$ & 0.6631 & 0.5877 & 0.0363 & 5.110 \\
\hline $\begin{array}{l}\text { in } 1980 \\
\text { RENTINC: Ratio of } \\
\text { average monthly rent } \\
\text { annualized to projected } \\
1987 \text { median income of the }\end{array}$ & 13.38 & 1.203 & 9.40 & 16.20 \\
\hline $\begin{array}{l}\text { property's zip code } \\
\text { RENTSF: Average monthly }\end{array}$ & 0.1476 & 0.0412 & 0.0722 & 0.4073 \\
\hline $\begin{array}{l}\text { gross rent per sq. } \mathrm{ft} \text {. } \\
\text { OUTSERV: Annual } \\
\text { expenditures per sq. } \\
\mathrm{ft} \text {. For services from }\end{array}$ & 0.4288 & 0.0937 & 0.2400 & 0.8200 \\
\hline $\begin{array}{l}\text { outside contractors } \\
\text { INCENTIV: Incentive } \\
\text { pay to property }\end{array}$ & 0.0273 & 0.0492 & 0.0000 & 0.3563 \\
\hline $\begin{array}{l}\text { employees per sq. } \mathrm{ft} \text {. } \\
\text { TURNOVER: Ratio of number } \\
\text { of units in the project } \\
\text { rented in } 1986 \text { to }\end{array}$ & 0.0204 & 0.0654 & 0.0000 & 1.000 \\
\hline $\begin{array}{l}\text { total number of units } \\
\text { WAGES: MSA or state } \\
\text { average hourly }\end{array}$ & 0.7503 & 0.2575 & 0.1607 & 1.645 \\
\hline industrial wage, 1986 & 9.860 & 1.290 & 6.990 & 13.73 \\
\hline
\end{tabular}

'Means and Standard deviations for the four ownership groups are $A 1$ : 1.456, 0.3012; A2: 1.432, 0.3025; $A 3$ : $1.538,0.4178$; and $A 4: 1.520,0.3101$. 
financial stakes in properties are likely to monitor operating expenses more closely than institutions that have more dispersed ownership. Individuals and small partnerships also may be more sensitive to short-term cash flow needs, and thus may be more inclined to terminate marginally performing management firms. The signs and significance of the AGENCGRP, OWNRSHIP and reformulated $A G E N C G R P$ variables indicate the importance of individual versus institutional ownership and ownership concentration for explaining variation in operating expenses.

The second hypothesis (market competition hypothesis) is that operating expenses are expected to be higher when there is no competition in the selection of property management firms. A reformulated $A G E N C G R P$ dummy variable, $R E L I N S T(1=A 4$, $0=A 1, A 3)$, contrasts ownership by related institutions in which no competition exists for property management services, with other ownership forms in which competition does exist.

Hypothesis three (operating expenses hypothesis) states that properties owned by individuals and private partnerships, in which either the general partner or owner is a key executive of the property management firm, experience lower advertising expenses per square foot and less turnover than other properties in the portfolio. These owners not only have a greater level of knowledge concerning normal operating expenses and tenant turnover, but also have more direct control over operations through their ability to hire, fire and promote property management personnel. By increasing the level of advertising and reducing the criteria of tenant selection, property managers may increase gross revenue. However, marked increases in advertising expenses or reduction in tenant selection standards may cause net operating income to fall. Regressions explaining both advertising expenses per square foot $(A S E F)$ and tenant turnover (TURNOVER) are run to test this hypothesis.

Finally, we hypothesize (incentive payment hypothesis) that if direct incentive compensation is paid to property management personnel for good performance, then agency costs will be lower. An incentive payment variable (INCENTIV) is included in the operating expense equation to test this hypothesis.

\section{RESULTS}

The results of regressing $O E S F$ on the full set of independent variables, excluding OWNRSHIP, INCENTIV, RELINST and RELPRIN, are shown in Table 3. The parameters of the model 
TABLE 3

Comparison of Functional Forms

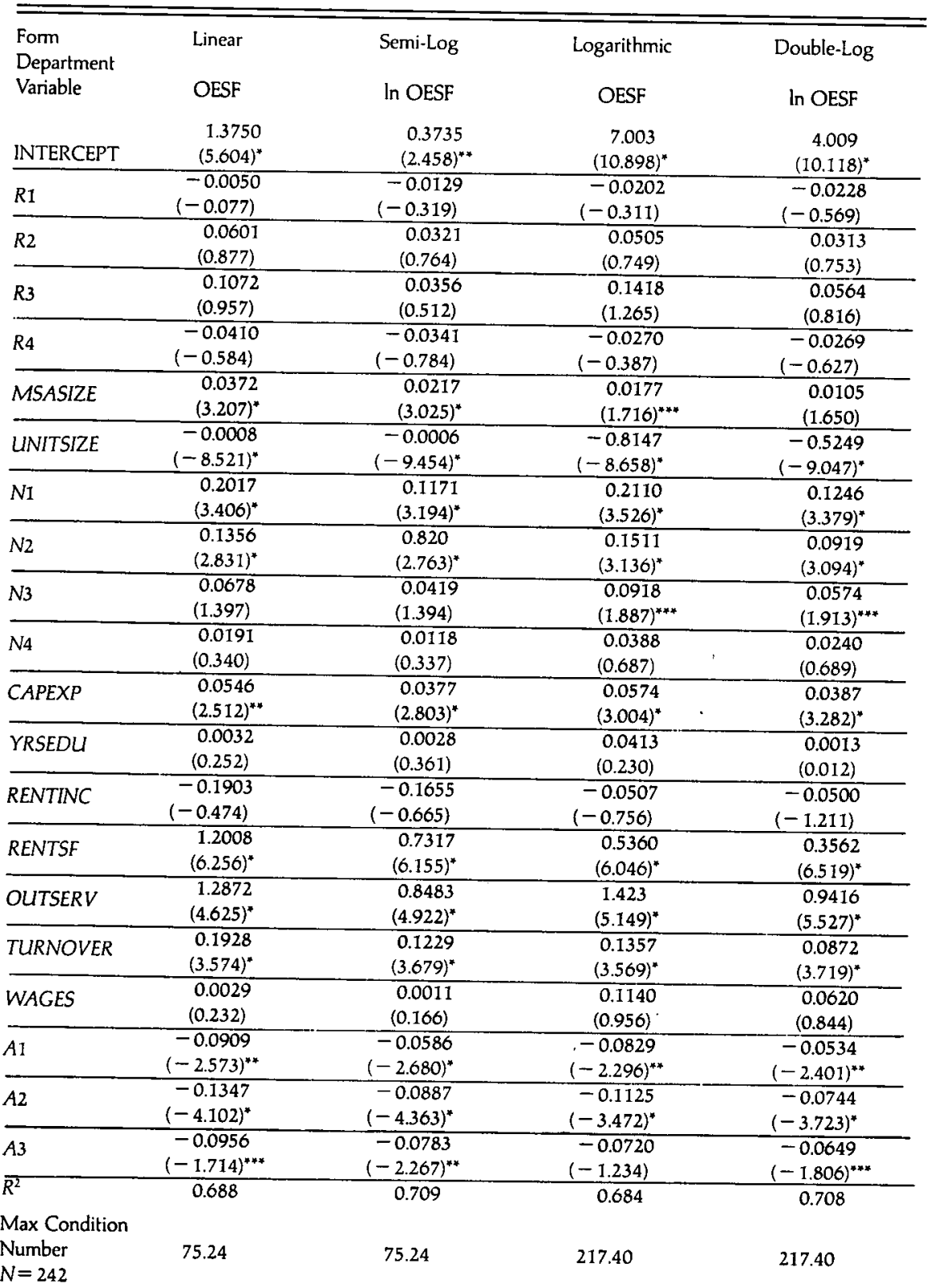

Coefficients are in the body of the table with $t$-ratios in parenthesis. Independent variables are logs when logarithmic and double log forms are tested except for OUTSERV and dummy variables $(R, N$, and $A$ ).

"significant at the 0.01 level "significant at the 0.05 level *** significant at the 0.10 level 
are estimated using four functional forms; linear, semi-log, logarithmic, and double-log. Taken together, the independent variables have high explanatory power, although some coefficients are not significantly different from zero. The signs and sizes of coefficients and the explanatory power of this model are not radically different under the four different functional forms. Multicollinearity is tested by using condition number, and the higher indices found in the logarithmic and double-log equations indicate that multicollinearity is a greater problem using these functional forms. ${ }^{3}$ Thus, tests of hypotheses were conducted using the linear form. The signs of the coefficient of the agency group variables are all negative and significant, indicating that the highest agency costs exist when owners and property managers are organizationally related (the default group).

Maximum condition numbers, however, revealed a high degree of multicollinearity among the independent variables with all functional forms. A comparison of the regression results and the correlation matrix also showed several cases in which opposite signs were found between regression coefficients and first-order correlation coefficients. Attempts were then made to construct models that reduced multicollinearity. For instance, variables within the same hypothesized vectors of characteristics were deleted. In some cases these equations had explanatory power nearly equal to the full model and all variables were significant at the 0.05 level. However, high condition numbers in diagnostic tests indicated that multicollinearity continued to be a problem. ${ }^{4}$

Factor analysis was chosen to lessen the effects of multicollinearity. 'This approach was deemed appropriate because the objective of the research is to test the effect of agency variables on $O E S F$ while holding the effects of other factors constant. Although the individual variables may no longer be identifiable after factor analysis, the variables of interest can be separated from the factors and tested in regression equations together with the factors. Guntermann and Norrbin [5] used this approach to reduce collinearity among variables measuring common area amenities in their study of apartment rents.

Principal component analysis was performed on the data using $O E S F$ as the dependent variable and the full set of

${ }^{3}$ Condition indices are the square roots of the ratio of the largest eigenvalue to each eigenvalue. A collinearity problem may exist when high condition indices are found [15].

${ }^{4}$ Tests were also conducted for heteroscedasticity, and no significant problem was discovered. 
independent variables, excluding agency variables of specific interest. The factors were rotated using the Varimax rotation method, and five factors were retained using the Mineigen One section criteria and plots.

Results of the first test of the ownership concentration hypothesis are presented in Table 4. Factors 1, 3, 4 and 5 are significant and the maximum condition number is reduced dramatically. ${ }^{5}$ Among the agency group variables, the coefficient of $A 2$ (individual/related) is significantly lower than the default group, $A 4$ (institutional/related). As hypothesized, OESF for the related private ownership group properties are significantly lower than for properties owned by related institutions. Based on the size of the coefficient of $A 2$ in Table 4, the per square foot loss resulting from reduced ownership control is $\$ 0.087$ or $6 \%$ of its mean value.

Ownership concentration effects were further tested by including in separate regressions OWNRSHIP $(1=$ principals of

\section{TABLE 4}

\section{Test of Ownership Concentration}

\begin{tabular}{lrc}
\hline \hline $\begin{array}{l}\text { Dependent Variable }=\text { OESF } \\
\text { Variable }\end{array}$ & Coefficient & $t$-Ratio \\
& & \\
INTERCEPT & 1.5203 & $76.039^{*}$ \\
Factor 1 & 0.1193 & $7.754^{*}$ \\
Factor 2 & 0.0204 & 1.289 \\
Factor 3 & -0.0405 & $-2.537^{* *}$ \\
Factor 4 & 0.2417 & $13.925^{*}$ \\
Factor 5 & 0.0340 & $2.022^{* *}$ \\
A1 (Individual/Unrel.) & -0.0363 & -0.914 \\
A2 (Individual/Rel.) & -0.0870 & $-2.461^{* *}$ \\
A.3 (Institution/Unrel.) & -0.0327 & -0.518 \\
$F=33.514$ & & \\
$R^{2}=0.5350$ & & \\
& & \\
Max. Condition & & \\
Number $=2.43$ & & \\
$N=242$ & & \\
& & \\
"significant at 0.01 level & & \\
"significant at 0.05 level & & \\
"** significant at 0.1 level & &
\end{tabular}

${ }^{5}$ Maximum condition numbers are also much lower from each of the other principal component regressions run to test the hypotheses in this study. 
the parent company own less than $50 \%$ ) and a reformulated $A G E N C G R P$ variable NEWAGEN $(1=A 1$ and $A 2$, the two individual ownership categories) in the $O E S F$ equation. As shown in Table 5, the coefficient on OWNRSHIP indicates no significant difference between properties in which principals have less than $50 \%$ ownership and the default category in which they owned $50 \%$ or more of the properties. However, as indicated by the significant coefficient of NEWAGEN, OESF for privately owned properties are significantly lower than institutionally owned properties primarily because of the degree of control exercised by private owners. This finding is not surprising given the results in Table 4.

The market competition hypothesis was tested in an $O E S F$ equation that included control factors and the variable RELINST $(1=A 4,0=A 1$ and $A 3)$. Operating expenses were not

TABLE 5

Further Tests of Ownership Concentration

\begin{tabular}{|c|c|c|}
\hline \multicolumn{3}{|l|}{ Dependent Variable $=O E S F$} \\
\hline \multicolumn{3}{|l|}{ Variable } \\
\hline \multirow[t]{2}{*}{ INTERCEPT } & 1.4440 & 1.5171 \\
\hline & $(35.512)^{*}$ & $(79.768)^{*}$ \\
\hline \multirow[t]{2}{*}{ Factor 1} & 0.0369 & 0.1188 \\
\hline & $(1.370)$ & $(7.824)^{*}$ \\
\hline \multirow[t]{2}{*}{ Factor 2} & -0.0224 & 0.0214 \\
\hline & $(-0.789)$ & (1.357) \\
\hline \multirow{2}{*}{ Factor 3} & 0.0936 & -0.0367 \\
\hline & $(3.234)^{*}$ & $(-2.349)^{* * 1}$ \\
\hline \multirow[t]{2}{*}{ Factor 4} & 0.2295 & 0.2403 \\
\hline & $(8.186)^{*}$ & $(13.894)^{*}$ \\
\hline \multirow[t]{2}{*}{ Factor 5} & 0.0307 & 0.0366 \\
\hline & $(0.999)$ & $(2.207)^{*}$ \\
\hline OWNRSHIP $(\mathrm{I}=$ & -0.0203 & - \\
\hline $\begin{array}{l}\text { less than } 50 \% \text { parent } \\
\text { ownership) }\end{array}$ & $(-0.369)$ & \\
\hline NEWAGEN $(1=\mathrm{A} 1$ and $\mathrm{A} 2)$ & - & $\begin{array}{l}-0.0627 \\
(-2.141)^{*}\end{array}$ \\
\hline$F$ & 13.764 & 44.515 \\
\hline$R^{2}$ & 0.6046 & 0.5320 \\
\hline \multicolumn{3}{|l|}{ Max. Condition } \\
\hline Number & 2.90 & 2.29 \\
\hline$N$ & $61^{1}$ & 242 \\
\hline
\end{tabular}

'Only the sixty-one observations in group A2 (individual/related) were considered in the OWNRSHIP test. "significant at 0.01 level

** significant at 0.05 level

*** significant at 0.10 level 
significantly different between the related institution's properties and other properties, thus failing to support the hypothesis that competition in the selection of property management reduces $O E S F$. Tests with TURNOVER and AESF on the left side of the equation produced low $R^{2}$ values and did not provide support for the hypothesis that related private owner properties had lower turnover and advertising expenses than other properties. Finally, tests of the incentive payment hypothesis, which involved the use of the variable INCENTIV, did not produce support for the notion that higher incentive payments result in lower $O E S F$.

\section{CONCLUSIONS}

In this paper, we examined the agency costs to property owners of entering into standard property management contracts. The empirical evidence shows that institutional owners incur significant agency costs in contracting for property management services. These costs are a function of the level of control exercised by owners, but not necessarily the extent of competition for property management services. Agency costs are the result of a conflict between the utility of owners and managers. This conflict exists because property management contracts offer no incentive for managers to reduce operating expenses and may offer incentives for managers to operate at expense levels that are excessive.

The results of the study show that agency costs, as measured by variable operating expenses per square foot, are significantly higher $(6 \%)$ for institutionally owned properties than for properties owned by individuals and small partnerships. However, the results do not support hypotheses that agency costs are reduced by competition in the market for property management services and that managers specifically abuse advertising expense and encourage tenant turnover to generate additional fees. Incentive compensation arrangements with employees also were not found to be important for reducing agency costs.

The weakness of the property management contract is that compensation is based on gross rental collections rather than on net operating income. While it is much simpler to administer contracts based on gross collections, the evidence of significant agency costs merits consideration of a change in standard property management contract provisions. The potential for residual losses should be considered in structuring property management compensation arrangements. Previous research in 
corporate finance and real estate has shown that contractually aligning the interests of owners and managers with respect to agent compensation reduces agency costs. Finally, as institutional ownership of real estate increases, agency problems in property management relationships will likely increase.

The authors are indebted to the two anonymous referees and Donald Haurin for suggestions that resulted in a much improved paper. All errors in the final version are the responsibility of the authors.

\section{REFERENCES}

[1] A. Barnea, R. A. Haugen and L. W. Senbet. Agency Problems and Financial Contracting. Prentice Hall, 1985.

[2] CACI, Inc. The Source Book of Demographic and Buying Power for Every Zip Code in the U.S.A. Fairfax, Virginia, 1987.

[3] J. H. Daub. Guerilla Marketing for Apartments. Journal of Property Management 57(7): 22-24, 1987.

[4] E. F. Fama. Agency Problems and the Theory of the Firm. Journal of Political Economy 88(2): 288-307, 1980.

[5] K. L. Guntermann and S. Norrbin. Explaining the Variability of Apartment Rents. AREUEA Journal 15(4): 321-40, 1987.

[6] J. W. Hoag. Toward Indices of Real Estate Value and Returns. Journal of Finance 35(2): 569-80, 1980.

[7] A. J. Jaffe. A Reexamination of the Problem of Management Fee Assessment. Journal of Property Management 44(1): 39-43, 1976.

[8] - Property Management in Real Estate Investment Decision-Marketing. Lexington Books, 1979.

[9] M. C. Jensen and W. H. Meckling. The Theory of the Firm: Managerial Behavior, Agency Costs, and Ownership Structure. Journal of Financial Economics 3(3): 305-60, 1976.

[10] W. J. Kim and E. H. Sorensen. Evidence of the Impact of the Agency Costs of Debt on Corporate Debt Policy. Journal of Financial and Quantitative Analysis 21(2): 131-44, 1986.

[11] R. C. Kyle. Property Management. The Real Estate Education Company, 1984.

[12] R. C. Lease, J. J. McConnell and W. H. Michelson. The Market Value of Control in Publicly Traded Corporations. Journal of Financial Economics 11(4): 439-71, 1983.

[13] S. Ross. The Economic Theory of Agency: The Principal's Problem. American Economic Review 63(2): 134-39, 1973.

[14] M. S. Rozeff. Growth, Beta, and Agency Costs as Determinants of Dividend Payout Ratios. Journal of Financial Research 5(3): 249-58, 1982. 
[15] SAS Institute Inc. SAS Users Guide: Statistics, Version 5 Edition. SAS Institute Inc., 1985.

[16] M. E. Solt and N. G. Miller. Managerial Incentives: Implication for Financial Performance of Real Estate Investment Trust. AREUEA Journal 13(4): 404-23, 1985.

[17] L T. Starks. Performance Incentive Fees: An Agency Theoretic Approach. Journal of Financial and Quantitative Analysis 22(1): 17-32, 1987.

[18] A. V. Thakor and T. S. Ramakrishnan. Moral Hazard, Agency Costs, and Asset Prices in Competitive Equilibrium. Journal of Financial and Quantitative Analysis 17(4): 503-32, 1982.

[19] U.S. Department of Labor, Bureau of Labor Statistics. Employment and Earnings. 1987.

[20] T. S. Zorn and J. E. Larsen. The Incentive Affect of Flat-Fee and Percentage Commission for Real Estate Brokers. AREUEA Journal 14(1): 24-47, 1986. 